Copyright (C) 2021 by Cherkas Global University

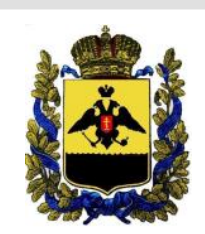

Published in the USA

Bylye Gody

Has been issued since 2006.

E-ISSN: $2310-0028$

2021. 16(4): 1857-1866

DOI: $10.13187 /$ bg.2021.4.1857

Journal homepage:

https://bg.cherkasgu.press

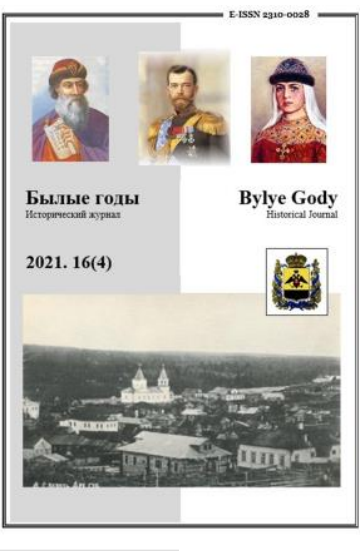

\title{
Socio-Economic Significance Orenburg-Tashkent Railway in the Syrdarya Region of the Turkestan General Government
}

\author{
Lazzat S. Dinasheva a, ${ }^{\text {* }}$, Murat M. Tastanbekov ${ }^{b}$, Gulmira Y. Sabdenova ${ }^{c}$, Tengesh S. Kalenova ${ }^{d}$ \\ ${ }^{a}$ Akhmet Yassawi International Kazakh-Turkish University, Turkistan, Kazakhstan \\ ${ }^{\mathrm{b}}$ Azret Sultan state historical-cultural reserve-museum, Turkistan, Kazakhstan \\ ${ }^{\mathrm{c}}$ Kazakh National University named after al-Farabi, Almaty, Kazakhstan \\ d L.N. Gumilyov Eurasian National University, Nur-Sultan, Kazakhstan
}

\begin{abstract}
The article is devoted to the analysis of the significance of the Orenburg-Tashkent railway in the socioeconomic life of the Syrdarya region of the Turkestan region. This railway line is considered as a mechanism that opened the way for the entry of the region into capitalist relations. Most of the railway line passed through the territory of the Syrdarya region. Among the regions included in the Turkestan Region, the Syrdarya region stands out for its geographical and socio-economic character. This is due to the fact that there were very few cities and industrial centers on the territory of the region.

The vast majority of residents led a semi-nomadic lifestyle. It was difficult for the peasants to get their goods transported to other consumer environments. It can be argued that this development trend has changed dramatically with the construction of the railway. Based on archival materials, an assessment of the activities of new railway stations and industrial facilities formed on the territory of the Syrdarya region is given. In addition, much attention is paid to the phenomenon of diversification of the labor sphere caused by the functioning of the railway. In the course of the research work, an objective approach to the factors of the construction of the Orenburg-Tashkent railway is revealed. As one of them, it is concluded that the factor of highway construction was carried out not because of competition between empires (as noted in many studies), but in order to involve the socio-economic isolated part of the empire in integration processes. Due to the activity of the railway, the export-import potential of the region has increased. The Syrdarya region has received ample opportunities for the export of salt, santonin, wool, dried fruits. In general, the railway line had a significant impact on the transition of the region from the old feudal relations to a partial agrarianindustrial form.
\end{abstract}

Keywords: Orenburg-Tashkent railway, Turkestan Governor-General, Syrdarya region, Central Asia, socio-economic factor, railway workers.

\section{1. Введение}

Вопрос о соединении Туркестанского края железнодорожным путем с центральной частью России был поставлен сразу же после образования Туркестанского генерал-губернаторства в 1867 году. В 1874 году была создана специальная железнодорожная комиссия под руководством первого генерал-губернатора Туркестана К.П. Кауфмана. Главной целью комиссии было изучение маршрута короткого пути, соединяющего Оренбург и Ташкент (Велецкий, 1910: 26). До начала строительства в 1900 году было предложено несколько линий дорог, которые связывали бы Центральную Россию с Туркестаном, в том числе в качестве проекта обсуждалось и ЗападноСибирское направление, которое через Тюмень, Акмолинск будет присоединено к Туркестану

${ }^{*}$ Corresponding author

E-mail addresses: dinash-lyazzat@mail.ru (L.S. Dinasheva), gulmira28@mail.ru (G.E. Sabdenova) 
(Безносиков, 1876: 14). Но в итоге железнодорожное сообщение между Оренбургом и Ташкентом было поддержано императором.

На наш взгляд, строительство железной дороги Оренбург-Ташкент предопределялось несколькими факторами, в том числе обеспечением обороноспособности Туркестанского военного округа, а также повышением уровня отстающего в социально-экономическом развитии Туркестанского края. С нашей точки зрения, несмотря на преобладание исследований о первом факторе (Исингарин, 2004: 79; Ахмеджанова, 1984: 15), роль второго - также является высокой.

В 1900 году, когда началось строительство железной дороги Оренбург-Ташкент, в состав Туркестанского генерал-губернаторства вошли 5 областей: Семиреченская, Сырдарьинская, Самаркандская, Ферганская и Закаспийская. Железнодорожная линия проходила в основном по территории Сырдарьинской области. Ход строительства железной дороги на территории Сырдарьинской области и его результаты сыграли большую роль в социально-экономическом плане. Завершение строительства привело к формированию новых населенных пунктов в Сырдарьинской области и диверсификации труда. Эффективность его хозяйственно-экономических и социальных следов можно увидеть и сегодня.

\section{2. Материалы и методы}

Исходя из темы исследования и характера источников, материалы можно разделить на несколько групп:

- Основную их часть представляют материалы Центрального государственного архива Казахстана (г. Алматы, Казахстан) и Центрального государственного архива Узбекистана (г. Ташкент, Узбекистан), в основном письма и приказы канцелярии Туркестанского генерал-губернатора, а также другие документы.

- Были привлечены материалы Туркестанского городского государственного архива (г. Туркестан, Казахстан), в документах которого сохранились сведения о строительстве железнодорожных станций и разъездов. Особенно ценными являются данные о деятельности водонапорных башен, предназначенных для заправки поездов. Также большой интерес представляют архивные источники о строительстве железнодорожных мостов, сооруженных в тот период.

При написании статьи были использованы методы классификации и анализа сведений, содержащихся в приказах и распоряжениях Туркестанского генерал-губернаторства и канцелярии Сырдарьинской области о строительстве в крае новых предприятий и производств. Кроме того, при изучении социально-экономических процессов в обществе, возникших в результате строительства и функционирования железной дороги Оренбург-Ташкент, мы руководствовались современными междисциплинарными методами исторической науки, такими как контент-анализ, полипарадигмальный и др. Также были предприняты попытки проанализировать актуальные вопросы на основе объективного принципа при оценке и изучении последствий труда представителей различных национальностей, принимавших участие в строительстве. В этом важно было отказаться от стереотипных взглядов на национальность и религиозную разобщенность.

\section{3. Обсуждение}

Роль железной дороги Оренбург-Ташкент, ставшей одним из первых символов прихода элементов индустриального общества в Центральную Азию, относится к числу слабо изученных тем в историографии. Многие исследователи признают, что строительство данной железной дороги являлось не только политико-идеологическим приоритетом, но и движущей силой социальноэкономического развития края (Избасарова, 2019: 1655; Верховский, 1910: 63).

В ходе анализа историографии, посвященной истории данной железной дороги, исследовательские работы можно разделить на 3 периода по хронологическому принципу: дореволюционный, советский и современный. Для историографии дореволюционного периода важное значение имели пути поиска методов управления и принципов развития железнодорожного хозяйства Российской империи. Направления исследований дореволюционных авторов основаны на концепции государственности: то есть железнодорожный транспорт должен функционировать в соответствии с политико-идеологическими интересами государства. Однако в контексте данного вопроса среди авторов преобладают противоречивые взгляды. В них прослеживаются разногласия в сравнении методов ведения железнодорожного хозяйства в Российской империи с другими странами. Например, А. Борзенко (Борзенко, 1888), анализируя возникновение железных дорог в России и принципы государственной железнодорожной политики, показывает ее аналогичные стороны с политикой французского правительства.

Труды И.С. Блиоха (Блиох, 1878) и А. Радцига (Радциг, 1896) посвящены анализу влияния путей сообщения на экономику и хозяйство в соответствующих регионах. Они доказали, что ускорение перевозок в регионе, сближение производств и рынков сбыта стимулировали развитие земледелия, скотоводства, ремесел, промышленности. Авторы отметили стратегическое значение железных дорог в сохранении обороноспособности Российской империи. 
Одним из первых проанализировал проект маршрута строительства железной дороги Оренбург-Ташкент К.С. Безносиков (Безносиков, 1876). Он назвал строительство железной дороги через Оренбург в Ташкент более коротким и дешевым проектом.

Одним из исследователей, сформировавших после завершения строительных работ концептуальное мнение о его результатах и перспективах, является М.Л. Юдин (Юдин, 1895). Он дал оценку первым доходам железнодорожной линии, поступившим в государственную казну, и дал прогноз на ее будущие показатели роста. В целом следует отметить, что М.Л. Юдин является первым исследователем, обосновавшим научное направление, касающееся роли железной дороги ОренбургТашкент в социально-экономическом развитии Оренбургского, Туркестанского краев.

П.П. Мигулин утверждал, что все железнодорожные линии в Российской империи строились за счет государственной казны. Автор обосновывает закономерность того, что вкладываемый в железнодорожную отрасль капитал должен служить интересам государства (Мигулин, 1903).

В обосновании суждений относительно разработки проекта расширения в восточном направлении железной дороги Оренбург-Ташкент и ее перспектив в развитии края следует отметить труд С.Н. Велецкого (Велецкий, 1910). В своей работе он указывает, что расширение железнодорожной линии в восточном направлении позволит улучшить социально-экономический потенциал нескольких населенных пунктов и малых городов Туркестана.

В анализе экономических аспектов железнодорожной сети Оренбург-Ташкент работы Т.А. Хворостанского имеют особое значение (Хворостанский, 1916). Исследователь отметил, что на рост экспорта пшеницы, хлеба, мучных изделий, транспортированных через Оренбург в 19101911 годах, повлияло строительство Ташкентской железной дороги. Кроме того, он внес ряд предложений по повышению эффективности использования данной железнодорожной сети.

Таким образом, историография дореволюционного периода отличается научно-практическим характером. В трудах подробно проаналазированы оптимальные проекты строительства железных дорог, изучены природно-экономические ресурсы, вклад железнодорожных линий в социальнохозяйственное развитие отдельных регионов и государства в целом. При этом необходимо учитывать, что вышеперечисленные авторы являлись не только исследователями происходящих событий, но и их непосредственными участниками.

Очевидно, что на направление исследовательских работ советского периода оказала влияние идеологическая цензура партии. В них прослеживается стремление сопоставить успехи советской железнодорожной деятельности с работой железнодорожной системы в имперский период.

Но стоит отметить и положительные стороны советской историографии. Они отличаются особым вниманием к изучению истории и деятельности отдельных железных дорог, в том числе и железной дороги Оренбург-Ташкент. Что немаловажно, труды советского периода были изданы в виде монографий, учебников, сборник материалов. Одним из них является работа Н.Д. Кондратьева, изданная в 1920-е годы (Кондратьев, 1922). В ней автором проведен системный анализ экономической значимости транспортного сообщения в отдельных регионах, однако элементы описания недостатков власти прошлого исторического периода относились к обязательной позиции, в том числе злоупотребление властью, эксплуатация труда рабочих, профессиональная некомпетентность и т.п.

Одним из тех, кто непосредственно занимался исследованием хозяйственно-экономического влияния железной дороги Оренбург-Ташкент, является А.В. Аксенов (Аксенов, 1955; Аксенов, 1958). В соответствии с научной конъюнктурой исследователь, отмечая, что строительство железной дороги вызвало развитие капиталистических отношений, пришел к выводу, что ее последствия привели к эксплуатации населения и богатства Туркестанского края (Аксенов, 1958: 67). Однако в своей кандидатской диссертации он дал оценку магистрали Оренбург-Ташкент как своего рода предприятия. По мнению автора, строительство железной дороги способствовало разрушению старых производственных отношений и поставило точку в многовековой феодальной и территориальной изоляции Центральной Азии (Аксенов, 1955).

В работах, опубликованных в 1960-1980-х годах, преобладает политический аспект: проведены комплексные исследования влияния железнодорожного транспорта на политические события, происходившие в государстве, в частности эвакуация красных рабочих из контрреволюционных сил, активность железнодорожников в процессе революции и др.

Во главе исследователей, занимавших критическую позицию в тот период, можно назвать С.Г. Струмилина (Струмилин, 1975) и Т.М. Китанину (Китанина, 1975). В своих работах они стремились объяснить тот факт, что железнодорожная политика имперского периода постоянно находилась в экономическом кризисе. По их мнению, строительство железных дорог сопровождалось элементами взяточничества, расточительности и т.д. (Струмилин, 1975: 34; Китанина, 1975: 59).

Отдельный интерес представляют труды М.Х. Асылбекова (Асылбеков, 1962), проводившего исследование влияния первой русской революции 1905-1907 гг. на сознание железнодорожных рабочих в Западно-Сибирском и Туркестанском краях.

Анализируя историографию советского периода в контексте проблемы, нужно подчеркнуть, что на нее было оказано сильное политическое и идеологическое влияние. Особенно много исследований 
в аспекте участия и вклада железнодорожников в революцию, организации партийных организаций на транспортных путях и модернизации дорог. Однако объем работ относительно роли железной дороги Оренбург-Ташкент и других магистралей в социально-экономическом развитии отдельного региона невелик.

Хотя на третьем этапе историографии не было такой идеологической цензуры, как в советское время, чрезмерная критика принципов прошлой историографии, политики колонизации, национальной эксплуатации и другие факторы привели к искажению объективности.

Можно убедиться в том, что функционирование железной дороги Оренбург Ташкент и ее различное влияние на обслуживаемую территорию не стали комплексной темой современной историографии. Учеными из России, Казахстана и Узбекистана были изданы исследовательские работы, рассматривавшие данную тему косвенно.

В подавляющем большинстве из них преобладает подход к рассмотрению магистрали как политического инструмента. Особенно важно признать, что это характерно для центральноазиатских авторов.

Казахстанский исследователь Н.К. Исингарин (Исингарин, 2004) в своей монографии рассмотрел политико-экономические аспекты строительства магистрали Оренбург-Ташкент. По мнению автора, эксплуатация магистрали позволила увеличить хозяйственно-производственный потенциал Туркестана.

В исследовании Г.Б. Избасаровой дана объективная оценка деятельности отдельных чиновников царской администрации, внесших вклад в строительство железной дороги ОренбургТашкент (Избасарова, 2019). Данная работа проводилась на основе анализа информации из газет, административных постановлений и решений, касающихся строительства железной магистрали.

Исследования узбекских авторов Х. Зиеева (Зиеев, 2006) и А.З. Тогаевой (Тогаев, 2009) направлены на частичный анализ роли железной дороги в социально-экономическом развитии города Ташкента и Самаркандской области. Однако в указанных работах наблюдаются элементы критического анализа и отклонения от объективной оценки.

В работах российских авторов всесторонне рассмотрены политико-экономические факторы функционирования железных дорог в период империи, в том числе роль железной дороги ОренбургТашкент. Основной объект исследований В. Шперлинга (Шперлинг, 20о6) обоснован тем, что строительство железных дорог в империи связано с освоением пространства империи. Он также дал весомую оценку интенсивным коммуникациям между местной элитой (купцы, помещики, дворяне и т.д.) и системой власти в контексте строительства железных дорог.

Ф.Б. Шенк (Шенк, 2010) придавал большое значение влиянию строительства железных дорог на межимперское и межнациональное соперничество.

И.В. Волков (Волков, 2013), уделив внимание факторам железнодорожных связей в развитии российского Туркестана, проанализировал различия между имперским и советским периодами. Однако отметим, что в вышеуказанных работах фактор железной дороги Оренбург-Ташкент в социально-экономическом развитии Сырдарьинской области не стал предметом специального исследования.

\section{4. Результаты}

В 1867 году был завершен процесс вхождения Центральной Азии в состав Российской имерии, произошло образование Туркестанского генерал-губернаторства (Хазретали..., 2018: 185). Перед царской администрацией стояла задача не только провести в крае реформы общественного образования и культуры, но и сформировать механизмы социально-экономического развития. Повышение социально-экономического потенциала Туркестана потребовало регулирования обеспечения внешних связей, ведь Туркестанский край уже много веков переживал цивилизационную изоляцию. В обществе существовали средневековые производственные подходы и социальные слои. На рынке труда сохранялись элементы рабовладельческой формы. Сельское хозяйство и ремесло носили примитивный характер. Пути формирования рабочего класса были закрыты (Волков, 2013: 93).

Вышеуказанные элементы отставания в развитии вызвали спрос на кардинальные изменения. Представители царской администрации ясно понимали, что первым шагом должно стать восстановление связей с европейской частью России. В первую очередь была поставлена задача увеличения экспортно-импортных возможностей региона (Мигулин, 1903: 61). Туркестанский край считался благоприятным для развития хлопка, ковров, животноводческой продукции, но нуждался в импорте металла, леса, муки, промышленных изделий (Радциг, 1896: 44). Несомненно, проблема удовлетворения указанных потребностей подтолкнула к регулированию сферы коммуникации. С 1870-х годов на правительственных заседаниях рассматривался вопрос о строительстве транспортного сообщения, связывающего Россию и Центральную Азию (Фурсов, Тестов, 2013: 28-29).

Первым железнодорожным сообщением, связавшим Россию и Туркестан, стала Закаспийская военная железная дорога, получившая впоследствии название Среднеазиатской. Среднеазиатская железная дорога протяженностью 2368 километров, полностью введенная в эксплуатацию в 
1899 году, вызвала ряд трудностей для транспортного сообщения Центральной Азии и России (Асылбеков, 1962: 56-57). Первая из них заключалась в том, что слишком большая протяженность пути и сложность доставки грузов паромом из Красноводска в Баку были экономически невыгодны.

Царское правительство начало планировать создание экономически выгодного и короткого транспортного сообщения. Его реализация стала возможной в 1906 году. Под личным контролем императора Николая II царская администрация с 1900 года взялась за проект строительства нового железнодорожного сообщения между Туркестаном и Россией (Россия..., 1903: 23). 10 мая 1901 года началось строительство железной дороги со стороны Оренбурга, 9 ноября - со стороны Ташкента. В сентябре 1906 года строительство железной дороги было официально введено в эксплуатацию (Асылбеков, 1962: 57). Протяженность железнодорожной магистрали, соединяющей Оренбург и Ташкент, составила 1668 км. Вдоль железнодорожной линии были построены новые города и промышленные центры.

Со строительством железной дороги улучшилось социально-экономическое положение населенных пунктов и малых городов - Актюбинска, Шалкара, Аральска, Перовска, Туркестана, Черняева (Велецкий, 1910: 19). Основные строительные работы железной дороги велись в Сырдарьинской области Туркестанского края, на территории которой было построено несколько железнодорожных разьездов и вокзалов. По данным архива, в 1901-1906 гг. в связи со строительством магистрали было построено 66 разъездов, 34 станции (ЦГА РК. Ф. 25. Оп. 1. Кн. 2. Д. 12. Л. 8). Необходимо отметить, что их деятельность продолжается и по сей день. Строительство вокзалов, станций и разъездов сопровождалось решением социально-хозяйственных вопросов той территории. Вместе со строительством новых объектов появились водонапорные башни для заправки поездов (Рисунок 1).

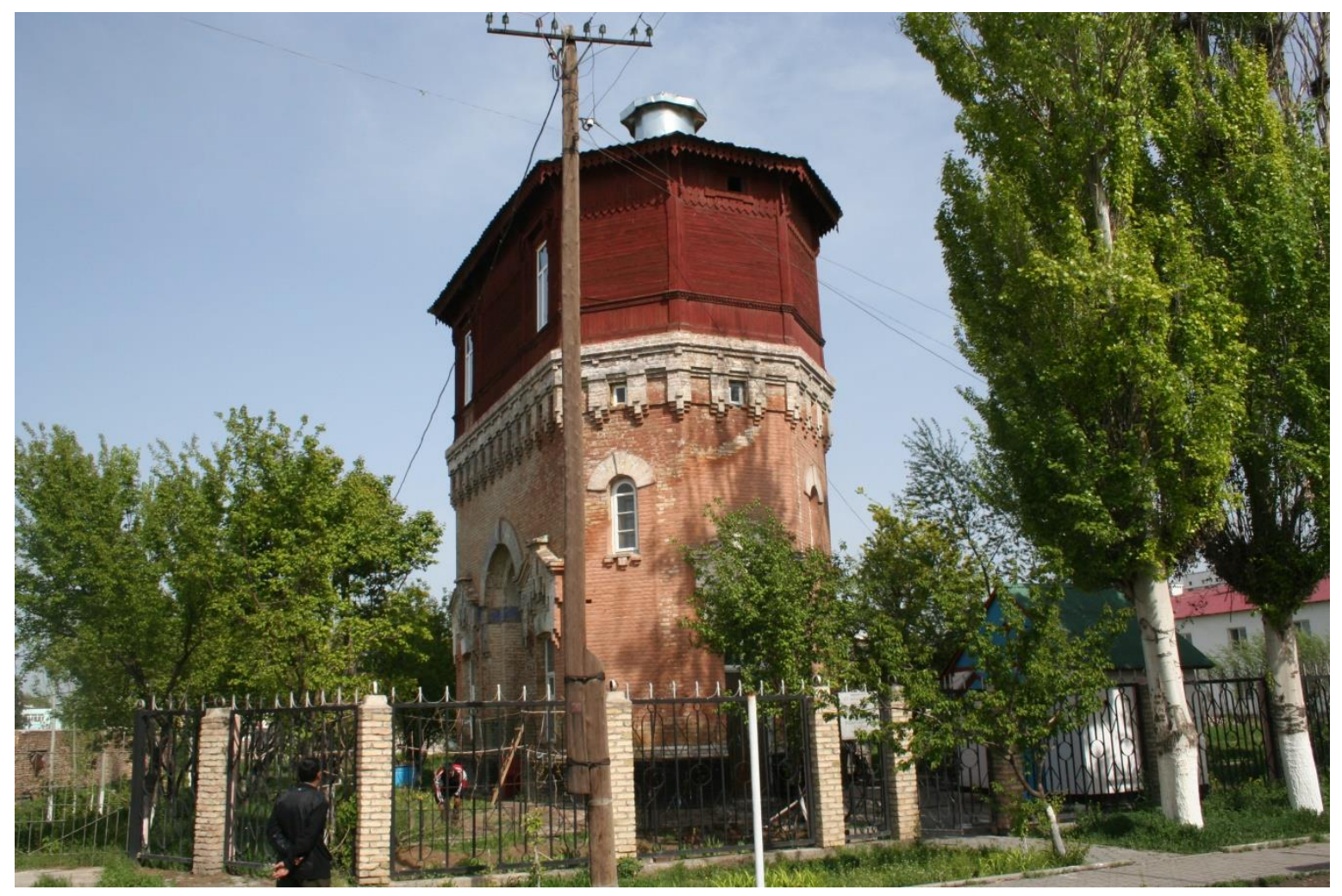

Рис. 1. Водонапорная башня, построенная в 1903 году на станции Туркестан

Они помогли решить проблему питьевой воды местного населения. Самое главное, что ход строительства железной дороги и его результаты сформировали новые профессии в местном обществе Сырдарьинской области и вызвали диверсификацию труда. Наряду с привлечением на строительство железной дороги специалистов и рабочих из России, была сформирована группа рабочих из местных жителей. По данным канцелярии Сырдарьинской области за 1904 год, в строительстве железной дороги было задействовано около 6 ооо человек из числа местного населения (ЦГА РК. Ф. 25. Кн. 2. Оп. 1. Д. 19. Л. 18). Заработная плата им выплачивалась в виде необходимых продуктов, например сахара, чая, масла, муки и т.д.. В 1905 году в Казалинске было введено в эксплуатацию первое локомотивное депо на магистрали (ЦГА РК. Ф. 25. Кн. 2. Оп. 1. Д. 7. Л. 36).

В 1906 году в Перовске была запущена работа депо веерного типа, в которое были приняты на работу 24 человека из числа местных жителей (ЦГА РК. Ф. 25. Кн. 2. ОП. 1. Д. 7. Л. 44). В 1906 году, 
после окончания основных строительных работ, появились дополнительные разъезды, станции. В 1907 году была запущена станция Сауран, в 1908 году - новый разъезд в селе Чернак близ города Туркестана (ТГГА. Ф. 2. Кн. 1. Оп. 1. Д. 5. Л. 23). Появление новых железнодорожных пунктов усилило процесс консолидации населения региона. Очевидно, что запуск железнодорожного сообщения привел к улучшению социально-экономического положения Сырдарьинской области: на ее территории были увеличены объемы инженерных строительных работ - вокзалов, мостов, водных башен. В 1906-1912 годах на участке дороги между Перовском и Черняевом было введено дополнительно 18 мостов (ЦГА РК. Ф. 25. Кн. 2. Оп. 1. Д. 7. Л. 52). Следует отметить, что их цель была сосредоточена на защите железной дороги от стихийных бедствий и обеспечении безопасности жизнедеятельности людей.

Оптимальное дорожное сообщение открыло возможность транспортировки промышленнохозяйственных изделий из промышленных зон Российской империи в Туркестан. Это явление послужило толчком к открытию новых предприятий и хозяйственных объектов. В 1906-1917 годах на территории Сырдарьинской области было введено около 14 новых предприятий. Большинство из них располагалось в городах Аральске, Черняеве, Перовске. В них работало более 1700 рабочих (Ахмеджанова, 1984: 115). В окрестностях городов, построенных вдоль железной дороги, процесс урбанизации населения шел медленно и стабильно. Если в Перовске в 1898 году проживало около 3250 человек, то в 1911 году его число достигло 11 тысяч (ЦГА РК. Ф. 25. Кн. 2. Оп. 1. Д. 9. Л. 29). Запуск кирпичного завода в Перовске в 1907 году стимулировал рост строительной отрасли: его продукция была способна обеспечить потребности не только Сырдарьинской, но и других областей. Так, в 1908 году было доставлено 12 вагонов кирпича в города Ташкент, Уральск (ЦГА РУ. Ф. 52. Кн. 2. Оп. 1. Д. 38. Л. 104).

Железная дорога ускорила развитие соляной промышленности в регионе, особенно на озерах близ Илецка и Казалы, в Перовском и Шымкентском уездах Сырдарьинской области. В связи с этим на Илецких промыслах в 1901-1904 гг. в среднем в год производилось 1,6 млн пудов соли, а в 19051907 гг. было произведено 2,3 млн пудов соли. Всего по дороге было перевезено: в 1905 году 1708 352, в 1906 году - 2680 480, в 1907 г. - 2208 о29 пудов соли. Крупнейшими пунктами отправки соли стали железнодорожные станции Оренбурга, Илецка, Чумыши, Жана-Кургана и др. (Материалы по Киргизскому землепользованию, 1915: 28). В 1910-1913 гг. по железной дороге было перевезено от 3,2 млн до 3,6 млн пудов соли (Материалы по Киргизскому землепользованию, 1915: 29).

По магистрали Оренбург-Ташкент в большом количестве стали перевозиться сухофрукты и вина. Через дорогу было перевезено: в 1906 г. - 88,6 тыс., в 1907 г. - более 90 тыс., в 1906 г. - около 47,2 тыс., в 1907 г. - около 47 тыс. пудов фруктов и сухофруктов (Исингарин, 2006: 119).

Железнодорожная деятельность способствовала не только увеличению грузоперевозок, сокращению времени в пути, но и ускорению оборота капитала, повышению эффективности работы производства. Большая часть продукции, произведенной в регионе, поставлялась в виде готовых товаров, а местный рынок стал частью общероссийского. На основе данных, по железной дороге в 1906-1907 гг. были перевезены от 3,8 до 5,0 млн пудов зерна, бакалейных и гастрономических товаров, сахара, железа и чугуна, а также машины и инструменты для обработки земли, нефть и керосин, каменный уголь и древесные строительные материалы и др. (Верховский, 1910: 42).

По состоянию на 1913 год парк подвижного состава железной дороги состоял из 531 паровоза, 7953 товарных и 495 пассажирских вагонов. В Ташкенте были построены депо, железнодорожные мастерские и открылись 25 училищ (ЦГА РУ. Ф. 41. Кн. 2. Оп. 1. Д. 18. Л. 55).

Еще одним эффективным фактором деятельности железной дороги Оренбург-Ташкент стало ускорение внутреннего товаро-пассажирского потока не только Сырдарьинской области, но и Туркестанского края в целом, то есть был упрощен механизм формирования связи расстояний между Югом и Севером области. Например, в 1910 году пассажиропоток между Перовском (северный пункт) и Ташкентом вырос в 2,5 раза по сравнению с 1906 годом. Если в 1906 году показатель пассажирских перевозок между двумя городами составлял 7,5 тыс. человек, то в 1910 году он достиг 19 тыс. (Хворостанский, 1916: 77).

Оренбургский край сыграл большую роль в торгово-экономических отношениях между Туркестаном и Россией. Строительство железной дороги способствовало дальнейшему развитию торгово-экономических связей между Туркестанским и Оренбургским генерал-губернаторствами. Этот фактор положительно отразился и на состоянии Сырдарьинской области. К концу XIX века товарооборот между Туркестаном и Оренбургом составил 3 миллиона рублей, а в 1910 году он вырос до 12,6 миллиона (Верховский, 1910: 41). В 1909 году на строительство водяной мельницы в селе Сайрам и моста через реку Сайрам из Оренбурга были привезены технические материалы и приглашены специалисты-строители. Построенная с их помощью водяная мельница способствовала повышению зернового потенциала региона (ЦГА РУ. Ф. І-1. Кн. 1. Оп. 33. Д. 399. Л. 9).

До строительства железной дороги Туркестанский край и Оренбург связывали два караванных пути (южный и северный) и время в караванном пути длилось несколько месяцев (согласно исследованиям, караваны из Ташкента в Оренбург шли 90-10о дней). Новое транспортное сообщение 
позволило сократить его срок в несколько раз: по железной дороге груз из Ташкента в Оренбург поступал за 14-15 дней (Глущенко, 2010: 187).

Функционирование железной дороги увеличило объем регионального товарооборота между центральными районами России и Центральной Азией, что открыло путь к процессу вхождения Туркестана в капиталистические отношения. Железнодорожная линия Оренбург-Ташкент кардинально изменила характер социально-экономического развития изолированного края империи.

С увеличением торгово-экономического потенциала края возросло количество торговых предприятий. В 1908 г. число торговых предприятий составляло около 47 тыс., а товарооборот равнялся 125 млн 885 тыс. руб. (Асылбеков, 1962: 59). Большая часть торговых предприятий принадлежала Сырдарьинской и Ферганской областям. Многие из них занимались хлопководством. Увеличение предприятий, занимающихся производством хлопка в Туркестане, в 1910 г. увеличило объем перевозки грузов в Россию на 16,5 млн пудов. А в 1911 году он составил 24 млн пудов (Волков, 2013: 98).

\section{5. Заключение}

Железная дорога Оренбург-Ташкент стала одним из факторов формирования рабочего класса в Сырдарьинской области Туркестанского края. С первых дней строительства казахи, узбеки и другие местные жители приняли активное участие в строительстве железной дороги, многие из которых впоследствии получили возможность работать на дороге.

Строительство железной дороги облегчило услуги межрегиональных перевозок товаров, что способствовало созданию нового этапа в процессах межрегиональной торгово-экономической интеграции.

Деятельность железной дороги Оренбург-Ташкент сыграла значительную роль не только в социально-экономической, но и в образовательно-культурной сферах Сырдарьинской области. Благодаря железной дороге увеличилось количество квалифицированных врачей, инженеров и учителей, прибывающих в регион.

\section{6. Благодарности}

Статья подготовлена в рамках гранта Министерства культуры и спорта Республики Казахстан «Комплексное исследование социально-экономической и культурной истории города Туркестана середины XIX - начала XXI века» (проект № 1016479).

\section{Литература}

Аксенов, 1955 - Аксенов А.В. Оренбургско-Ташкентская железная дорога и ее роль в развитии капитализма в Средней Азии: Автореф. дисс. ... анд. ист. наук. М., 1955.

Аксенов, 1958 - Аксенов А.В. Строительство Оренбургско-Ташкентской ж.-д. 1901-1905 гг. // Ученые записки ОГПИ. 1958. № 13. С. 22-26.

Асылбеков, 1962 - Асылбеков М.X. Некоторые вопросы истории строительства ОренбургскоТашкентской железной дороги // Известия АН КазССР. 1962. № 2 (19). С. 55-62.

Ахмеджанова, 1984 - Ахмеджанова З.К. Железнодорожное строительство в Средней Азии и в Казахстане (конец XIX - начало XX в.). Ташкент: Наука, 1984.

Безносиков, 1876 - Безносиков К.С. Описание направлений для предполагаемых железных дорог из г. Оренбурга и г. Челябы в Ташкент // Оренбургский листок. 1876. № 2. C. 8-34.

Блиох, 1878 - Блиох И.С. Влияние железнодорожного транспорта на экономическое состояние России. СПб., 1878.

Борзенко, 1881 - Борзенко А. Материалы по железнодорожным вопросам. Железные дороги в Англии, Франции и России. Ярославль, 1881.

Велецкий, 1910 - Велецкий C.Н. Железная дорога в Семиречье. Верный, 1910.

Верховский, 1910 - Верховский Н.П. Туркестан в районе Ташкентской железной дороги и грузы этой дороги. СПб., 1910.

Волков, 2013 - Волков И.В. Железнодорожные коммуникации как фактор развития русского Туркестана // Пространство и Время. 2013. № 3. С. 92-98.

Глущенко, 2010 - Глущенко E.A. Россия в Средней Азии. Завоевания и преобразования. М.: Центрполиграф, 2010.

Зиеев, 2006 - Зиеев X. Узбекистон мустамлака ва зулм исканжасида (XIX аср иккинчиярми XX аср бошлари). Ташкент: Шарк, 2006.

Исингарин, 2004 - Исингарин Н.К. Железные дороги Казахстана: становление и развитие. Алматы: Рауан, 2004.

Китанина, 1975 - Китанина T.М. Хлебная торговля России в 1875-1914 гг. М., 1975.

Кондратьев, 1991 - Кондратьев Н.Д. Рынок хлебов и его регулирование во время войны и революции. М., 1991.

Материалы по Киргизскому землепользованию, 1915 - Материалы по Киргизскому землепользованию. Сыр-Дарьинская область, Перовский уезд. Ташкент, 1915. 
Мигулин, 1903 - Мигулин П.П. Наша новейшая железнодорожная политика и железнодорожные займы. 1893-1902. Харьков, 1903.

Радциг, 1896 - Радциг А. Влияние железных дорог на сельское хозяйство, промышленность и торговлю. СПб., 1896.

Россия..., 1903 - Россия. Полное географическое описание нашего отечества. T. XVIII. Киргизский край. СПб., 1903.

Струмилин, 1975 - Струмилин С.Г. Очерки экономической истории России и СССР. М., 1966;

ТГГА - Туркестанский городской государственный архив.

Тогаева, 2009 - Тогаева А. Из истории железной дороги // Moziydan sado (Эхо uстории). 2009. № 2. C. 39-46.

Фурсов, Тестов, 2013 - Фурсов В.Н., Тестов В.Н. Возведение и функционирование транскаспийской магистрали в 80-х - начале 90-х гг. XIX в. // Научные ведомости Белгородского государственного университета. Серия «История. Политология. Экономика. Информатика». 2013. № 15 (158). С. 26-33.

Хворостанский, 1916 - Хворостанский Т.A. Оренбургский хлебный рынок. Оренбург, 1916.

Шенк, 2010 - Шенк Ф.Б. Imperial inter-rail: влияние межнационального и межимперского восприятия и соперничества на политику железнодорожного строительства в царской России // Imperium inter pares: Роль трансферов в истории Российской империи (1700-1917). Сб. ст. / Ред. Мартин Ауст, Рикарда Вильпиус, Алексей Миллер. М., 2010. С. 354-380.

Шперлинг, 2006 - Шперлинг В. Строить железную дорогу, создавая имперское пространство: «местность», «край», «Россия», «империя» как политические аргументы в пореформенной России // Ab imperio. 2006. № 2. С. 101-134.

ЦГА РК - Центральный государственный архив Республики Казахстан.

ЦГА РУ - Центральный государственный архив Республики Узбекистан.

Юдин, 1895 - Юдин М.Л. Средне-Азиатская железная дорога и преимущества направления ее от г. Оренбурга на г. Ташкент // Журнал Оренбургской Городской Думы. 1895. № 160. С. 1-17.

Khazretali..., 2018 - Khazretali T.M., Girtilioglu M., Omarbayev Y.K., Adilbayeva A.S. The Kazakh nobility in the formation of the state institutions of the Russian Empire in Semirechye // Bylye Gody. 2018. 47(1): 183-192.

Izbasarova, 2019 - Izbasarova G.B. Orenburg-Tashkent Railway and the Kazakh Society at the turn of the XIX-XX centuries(on the example of the Turgai region) // Bylye Gody. 2019. Vol. 54. Is. 4: $1647-1655$.

\section{References}

Ahmedzhanova, 1984 - Ahmedzhanova, Z.K. (1984). Zheleznodorozhnoe stroitel'stvo v Srednej Azii i v Kazahstane (konec XIX - nachalo XX v.) [Railway construction in Central Asia and Kazakhstan (late XIX early XX century)]. Tashkent: Nauka. [in Russian]

Aksenov, 1955 - Aksenov, A.V. (1955). Orenburgsko-Tashkentskaya zheleznaya doroga i ee rol'v razvitii kapitalizma v Sredney Azii.: Avtoref. dis. ...kan. ist. nauk. M., 1955. [Orenburg-Tashkent Railway and its role in the development of capitalism in Central Asia: Author. dis. ... candidate of Hist. sciences]. M. [in Russian]

Aksenov, 1958 - Aksenov, A.V. (1958). Stroitel'stvo Orenburgsko-Tashkentskoi zheleznoi dorogi 1901 1905 gg. [Construction of the Orenburg-Tashkent railway 1901 - 1905.]. Uchyonye zapiski OGPI. 13: 22-26. [in Russian]

Asylbekov, 1962 - Asylbekov, M.H. (1962). Nekotorye voprosy istorii stroitel'stva OrenburgskoTashkentskoj zheleznoi dorogi [Some questions about the history of the construction of the OrenburgTashkent railway]. Izvestiya AN KazSSR. 19(2): 55-62. [in Russian]

Beznosikov, 1876 - Beznosikov, K.S. (1876). Opisanie napravlenij dlya predpolagaemyh zheleznyh dorog iz g. Orenburga i g. Chelyaby v Tashkent [Description of the directions for the proposed railways from Orenburg and Chelyabinsk to Tashkent]. Orenburgskii listok. 2: 8-34. [in Russian]

Blioh, 1878 - Blioh, I.S. (1878). Vliyanie zheleznodorozhnogo transporta na ekonomicheskoe sostoyanie Rossii [The impact of rail transport on the economic state of Russia]. SPb. [in Russian]

Borzenko, 1881 - Borzenko, A. (1881). Materialy po zheleznodorozhnym voprosam. Zheleznye dorogi v Anglii, Francii i Rossii [Materials on railway issues. Railways in England, France and Russia]. Yaroslavl'. [in Russian]

CGA RK - Centralny gosudarstvenny arhiv Respubliki Kazahstan [Central State Archive of the Republic of Kazakhstan].

CGA RU - Centralny gosudarstvenny arhiv Respubliki Uzbekistan [Central State Archive of the Republic of Uzbekistan].

Fursov, Testov, 2013 - Fursov, V.N., Testov, V.N. (2013). Vozvedenie i funkcionirovanie transkaspijskoj magistrali v 80-h-nachale 90-h gg. XIX v [Construction and operation of the Trans-Caspian highway in the 80s-early 9os of the XIX century.]. Nauchnye vedomosti Belgorodskogo gosudarstvennogo universiteta. Seriya: Istoriya. Politologiya. Ekonomika. Informatika. 15(158): 26-33. [in Russian] 
Glushchenko, 2010 - Glushchenko, E.A. (2010). Rossiya v Srednei Azii. Zavoevaniya i preobrazovaniya [Russia in Central Asia. Conquests and transformations]. M.: Centrpoligraf. [in Russian]

Hvorostanskii, 1916 - Hvorostanskii, T.A. (1916). Orenburgskii hlebni rynok [Orenburg Bread Market]. Orenburg. [in Russian]

Izbasarova, 2019 - Izbasarova, G.B. (2019). Orenburgsko-Tashkentskaya zheleznaya doroga i kazahskoe obshchestvo na rubezhe XIX-XX vv. (na primere Turgaiskoi oblasti) [Orenburg-Tashkent Railway and the Kazakh Society at the turn of the XIX-XX centuries (on the example of the Turgai region)]. Bylye Gody. 54(4): 1647-1655. [in Russian]

Isingarin, 2004 - Isingarin, N.K. (2004). Zheleznye dorogi Kazahstana: stanovlenie i razvitie [Railways of Kazakhstan: formation and development]. Almaty: Rauan. [in Russian]

Khazretali...., 2018 - Khazretali, T.M., Girtilioglu, M., Omarbayev, Y.K., Adilbayeva, A.S. (2018). Kazahskaya rodovaya znat' v formirovaniya gosudarstvennyh institutov Rossijskoj imperii v Semirech'e [The Kazakh nobility in the formation of the state institutions of the Russian Empire in Semirechye]. Bylye Gody. 47 (1): 183-192. [in Russian]

Kitanina, 1975 - Kitanina, T.M. (1975). Hlebnaya-torgovlya Rossii v 1875-1914 gg. [Grain trade in Russia in 1875-1914]. M. [in Russian]

Kondrat'ev, 1991 - Kondrat'ev, N.D. (1991). Rynok hlebov i ego regulirovanie vo vremya vojny i revolyucii [The bread market and its regulation during the war and revolution]. M. (pervoe izdanie raboty sostoyalos' v 1922 g.). [in Russian]

Materialy po Kirgizskomu zemlepol'zovaniyu, 1915 - Materialy po Kirgizskomu zemlepol'zovaniyu. (1915). [Materials on Kyrgyz land use]. Syr-Dar'inskaya oblast', Perovskiy uyezd. Tashkent.

Migulin, 1903 - Migulin, P.P. (1903). Nasha novejshaya zheleznodorozhnaya politika i zheleznodorozhnye zajmy. 1893-1902 [Our latest railway policy and railway loans. 1893-1902]. Har'kov. [in Russian]

Radcig, 1896 - Radcig, A. (1896). Vliyanie zheleznyh dorog na sel'skoe hozyajstvo, promyshlennost' i torgovlyu [The impact of railways on agriculture, industry and trade]. SPb. [in Russian]

Rossiya, 1903 - Rossiya. Polnoye geograficheskoye opisaniye nashego otechestva. (1903). [Russia. Full geographical description of our Father-land]. T. XYIII. Kirgizkiy kray. Saint-Petersburg. [in Russian]

Strumilin, 1975 - Strumilin, S.G. (1975). Ocherki ekonomicheskoj istorii Rossii i SSSR [Essays on the Economic History of Russia and the USSR]. M. [in Russian]

TGGA - Turkestanskii gorodskoi gosudarstvenni arhiv (Turkestan City State Archive).

Togaeva, 2009 - Togaeva, A. (2009). Iz istorii zheleznoi dorogi [From the history of the railway]. Moziydan sado (Ekho istorii). 2: 39-46.[in Russian]

Shenk, 2010 - Shenk, F.B. (2010). Imperial inter-rail: vliyanii mezhnacional'nogo i mezhimperskogo vospriyatiya i sopernichestva na politiku zheleznodorozhnogo stroitel'stva v carskoy Rossii [On the influence of interethnic and inter-empire perception and rivalry on the policy of railway construction in Tsarist Russia]. Imperium inter pares: Rol' transferov $\mathrm{v}$ istorii Rossiiskoi imperii (1700-1917). [Imperium inter pares: The role of transfers in the history of the Russian Empire]. Sb. st. Red. Martin Aust, Rikarda Vil'pius, Aleksei Miller. M. Pp. 354-380. [in Russian]

Shperling, 2006 - Shperling, V. (2006). Stroit' zheleznuyu dorogu, sozdavaya imperskoe prostranstvo: «mestnost'», «krai», «Rossiya», «imperiya» kak politicheskie argumenty v poreformennoi Rossii [To build a railway, creating an imperial space: "locality", "land", "Russia", "empire" as political arguments in post- reform Russia]. Ab imperio. 2: 101-134. [in Russian]

Veleckij, 1910 - Veleckii, C.N. (1910). Zheleznaya doroga v Semirech'e [Railway in Semirechye]. Verni. [in Russian]

Verhovskii, 1910 - Verhovskii, N.P. (1910). Turkestan v raione Tashkentskoi zheleznoi dorogi i gruzy etoi dorogi [Turkestan in the area of the Tashkent railway and the cargo of this road]. SPb. [in Russian]

Volkov, 2013 - Volkov, I.V. (2013). Zheleznodorozhnye kommunikacii kak faktor razvitiya russkogo Turkestana. Prostranstvo i Vremya. 3: 92-98. [in Russian]

Yudin, 1895 - Yudin, M.L. (1895). Sredne-Aziatskaya zheleznaya doroga i preimushchestva napravleniya eyo ot goroda Orenburga na gorod Tashkent [The Central Asian railway and the advantages of the direction from the city of Orenburg to the city of Tashkent]. Zhurnal Orenburgskoj Gorodskoj Dumy. 160: 1-17. [in Russian]

Ziyoev, 2006 - Ziyoev, X. (2006). Uzbekiston mustamlaka va zulm iskanzhasida (XIX asr ikkinchi yarmi - XX asr boshlari) [Uzbekistan in the era of colonization and oppression (the second half of the XIX early XX centuries)]. Tashkent: Shark. [in Uzb.] 


\title{
Социально-экономическое значение железной дороги Оренбург-Ташкент в Сырдарьинской области Туркестанского генерал-губернаторства
}

\author{
Лаззат Сарсембековна Динашева a , *, Мурат Мейрбекович Тастанбеков \\ Гульмира Есбатыровна Сабденова ${ }^{c}$, Тенгеш Серикбаевна Каленова d
}

a Международный Казахско-Турецкий университет имени Ходжи Ахмеда Ясави, Туркестан, Казахстан b Государственный историко-культурный заповедник-музей «Азрет-Султан», Туркестан, Казахстан

c Казахский национальный университет им. аль-Фараби, Алматы, Казахстан

d Евразийский национальный университет им. Л.Н. Гумилева, Нур-Султан, Казахстан

\begin{abstract}
Аннотация. Статья посвящена анализу значения железной дороги Оренбург-Ташкент в социально-экономической жизни Сырдарьинской области Туркестанского края. Данная железнодорожная линия рассматривается как механизм, открывший путь к вступлению края в капиталистические отношения. Большая ее часть проходила по территории Сырдарьинской области, которая выделялась своим географическим и социально-экономическим положением из областей, входящих в Туркестанский край, тем, что на ее территории было очень мало городов и промышленных очагов.

Подавляющее большинство жителей вело полукочевой образ жизни. Крестьянам было трудно добиться перевозки своих товаров в другие потребительские среды. Можно утверждать, что данная тенденция развития резко изменилась со строительством железной дороги. На основе архивных материалов дана оценка деятельности новых железнодорожных станций и промышленных объектов, сформировавшихся на территории Сырдарьинской области. Кроме того, большое внимание уделено явлению диверсификации трудовой сферы, вызванному функционированием железной дороги. В ходе исследовательской работы был выявлен объективный подход к факторам строительства железной дороги Оренбург-Ташкент. В работе делается вывод о том, что строительство магистрали осуществлялось не из-за конкуренции между империями (как отмечалось во многих исследованиях), а с целью вовлечения в интеграционные процессы социально и экономически изолированной части империи. В связи с деятельностью железной дороги увеличился экспортно-импортный потенциал региона. Сырдарьинская область получила широкие возможности по экспорту соли, сантонина, шерсти, сухофруктов. В целом железнодорожная линия оказала существенное влияние на переход края от старых феодальных отношений к частично аграрно-индустриальной форме.

ключевые слова: железная дорога Оренбург-Ташкент, Туркестанское генералгубернаторство, Сырдарьинская область, Центральная Азия, социально-экономический фактор, железнодорожники.
\end{abstract}

\footnotetext{
${ }^{*}$ Корреспондирующий автор Адреса электронной почты: dinash-lyazzat@mail.ru (Л.С. Динашева), gulmira28@mail.ru (Г.Е. Сабденова)
} 